\title{
478．X線管電圧波形の周波数解析法（第3 報）
}

\author{
Frequency Analysis of Tube Voltage Waveform. (3rd report)
}

\author{
東北大学医学部胕属病院放射湶部 \\ O千田浩一 政博 浜尾典子 槏田秀晴 佐々木正寿 \\ K. Chida M. Sa i N. Hamao H. Sakakida M. Sasaki \\ 有馬宏車 \\ H. Arima
}

【目的】我々は管電压波形の新しい評価法として周波数解析法を提案し、前回までその基礎的な検討 を行い有用性について述べてきた。今回更に詳細な評価法として、F F T 解析から得られる種々の特 性值（各周波数成分の強度やオーバーオール值等）を用い、より客観的な比較が可能か検討した。

【方法】測定システムは基本的に今までと同様であり、X線管側にブリーダ(ALCO.KV-201D)を接続し、 その出力信号をANALYZING RECORDER(YOKOGATA Mode1.3655E)に取り込み、付属の F F T モジュール(M odel.3659.201)を使用しパワースペクトルを計測し、それから種々の特性值を求めた。使用したX線 装置は、単相（日立DR-155）、三相（日立DH-158HM，東芝KX0-850N）、定電庄（島津SHD-150G）であ る。全 X線装置を同一条件下で比較できるように、実験は $00.1 \mathrm{kV}$ の精度で行い、F F T 解析の際の

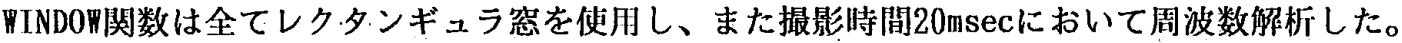

【結果】本測定システムでは主周波数成分の強度の他に、 $0 \mathrm{~Hz}$ つま直流成分の強度む求める事ができる。T able 1 は各X線装置の管電在波形の直流成分の強度を比較し たもので、当然定電厓装置が一番多く12peak, 6peak, 2pe akの順に直流成分が少なくなっている。T able 2 に 2 pe ak装置での直流および, $100 \mathrm{~Hz}$ 成分の強度を示す。本 X線 装置は低m A 時、管電圧波形は歪んだ形状となるが, 100 $\mathrm{mA}$ の方が, $300 \mathrm{~m}$ A に比べ淔流成分が多く、主周波数成 分である, $100 \mathrm{~Hz}$ 強度は小さくなっている。T able 3 は 6 および12peak装置における各周波数成分の強度の比較 である。直流成分は12peak装置の方が多い。300Hzの強 度は 6 peak装犆の方が大きく（ 6 peak装㧽の主周波数成 分であるため）、600Hzの強度は12peak装置にのみ存在 する（12peak装固の主周波数成分であるため）。 $\mathrm{T}$ able 4 は定電圧装置の直流成分について、管電圧管電流を変 化させ比較したものである。本X線装置は管電流を变化 させても直流成分の強度は変わらず、管電流により管電 正波形の形状は変化しない事を示す。また当然、高管電 圧の方が、直流成分の強度は大きい。Fig.は各X線装置 における、オーバーオール值を比較したもので定電圧装 置の $100 \mathrm{kV}$ を相対強度 1 として表示したものである。才 一バーオール值とは、全周波数成分（酒流成分も含む） の强度を積分したもので、同一管電圧で、その值が大き いほどX線出力（あるいは線質）が大きいと、大概考え る事ができる。予めそれらとの関係を知っておけば、才 一バーオール值は X 線出力等を知る指標として使用でき る可能性がある。

\begin{tabular}{|c|c|c|c|c|}
\hline & \multicolumn{4}{|c|}{$x-r a y$ ganerator } \\
\hline & 2 peak & 6 peak & 12 pesk & constant potential. \\
\hline Intensity & $\begin{array}{l}564.94 \\
(0.32)\end{array}$ & $\begin{array}{l}1264.70 \\
(0.72)\end{array}$ & $\begin{array}{l}1485.64 \\
(0.85)\end{array}$ & $\begin{array}{l}1745.82 \\
(1.00)\end{array}$ \\
\hline & & $m 4,20$ & ( & ): rolative intens \\
\hline
\end{tabular}

[ T able 1]

\begin{tabular}{|c|c|c|}
\hline \multirow{2}{*}{ frequency } & \multicolumn{2}{|c|}{ tube current } \\
\hline & $100 \mathrm{~mA}$ & $300 \mathrm{~mA}$ \\
\hline $\mathrm{OHz}$ & $\begin{array}{l}1828.10 \\
(1.17)\end{array}$ & $\begin{array}{l}1555.97 \\
(1.00)\end{array}$ \\
\hline $100 \mathrm{~Hz}$ & $\begin{array}{l}1004.62 \\
(0.85)\end{array}$ & $\begin{array}{r}1180.32 \\
(1.00)\end{array}$ \\
\hline
\end{tabular}

[T able 2]

\begin{tabular}{|c|c|c|}
\hline \multirow{2}{*}{ frequency } & \multicolumn{2}{|c|}{ x-ray generator } \\
\hline & 6 peak & 12 poak \\
\hline $\mathrm{O} \mathrm{Hz}$ & $\begin{array}{c}2301.40^{\circ} \\
(0.83)\end{array}$ & $\begin{array}{l}2766,94 \\
(1,0.0)\end{array}$ \\
\hline $300 \mathrm{~Hz}$ & $\begin{array}{l}16.29 \\
(1.55)\end{array}$ & $\begin{array}{l}10.52 \\
(1.00)\end{array}$ \\
\hline $600 \mathrm{~Hz}$ & $(-)$ & $\begin{array}{l}2.64 \\
(1.00)\end{array}$ \\
\hline
\end{tabular}

[Table 3]

\begin{tabular}{ccc}
\hline \multirow{2}{*}{ tubo voltage } & \multicolumn{2}{c}{ tubecurrent } \\
\cline { 2 - 3 } & $200 \mathrm{~mA}$ & $400 \mathrm{~mA}$ \\
\hline $80 \mathrm{kV}$ & 3033.89 & 3033.89 \\
\hline $100 \mathrm{kV}$ & 4698.94 & 4698.94 \\
\hline
\end{tabular}

【まとめ】管電压波形の周波数解析結果から得られる種 々の特性值に着目し検討を行ったが、唺流成分や各周波 数成分の強度を数值しして客観的に比較する事が可能で あるため、より詳細な性能の把握が行えた。そのため本 手法は、管電圧波形の計測栖価において有用性が高いほ か、X線装置管理の際も、有用であると思われた（管電 圧波形の歪みの定期的なチェック）。

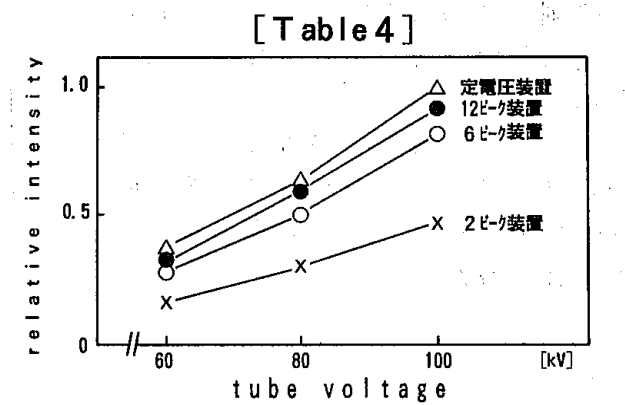

